\title{
Performance assessment of solar dryer for processing perishable vegetables
}

\author{
- Binapani Deka* and Mousumi Phukon \\ Krishi Vigyan Kendra (AAU), Jorhat (Assam) India \\ Email: dbinapani@gmail.com \\ *Author for Correspondence \\ Research chronicle : Received : 01.05.2018; Revised : 13.05.2018; Accepted : 21.05 .2018
}

\begin{abstract}
SUMMARY :
Drying is the moisture removing process from the products. Drying is very important process applicable for agricultural and industrial products. Drying reduces the bacterial growth in the products. It will helpful for preserving the products for long time. Open air and uncontrolled sun drying is still the most common method used to preserve and process Agricultural product. But uncontrolled drying suffers from serious problem of wind born dust, infestation by insect, product may be totally damaged. Solar drying is the oldest method of products drying. Local made solar dryers have been developed and used to dry agricultural products in order to improve shelf-life. The objective of this study is to see the advantages of solar dryer on their effectiveness in the drying of agricultural products. The findings showed that the solar dryer is beneficial than the sun drying techniques. Solar dryers have shortcomings. They are of little use during cloudy weather. During fair weather they can work too well. Although solar dryers involve an initial expense, they produce better looking, better tasting, and more nutritious foods, enhancing both their food value and their marketability. They are faster, safer and more efficient than traditional sun drying techniques.
\end{abstract}

KEY WORDS : Solar dryer, Processing perishable, Vegetables

How to cite this paper : Deka, Binapani and Phukon, Mousumi (2018). Performance assessment of solar dryer for processing perishable vegetables. Internat. J. Proc. \& Post Harvest Technol., 9 (1) : 10-14. DOI: 10.15740/HAS/IJPPHT/9.1/10-14. Copyright@ 2018: Hind Agri-Horticultural Society. 